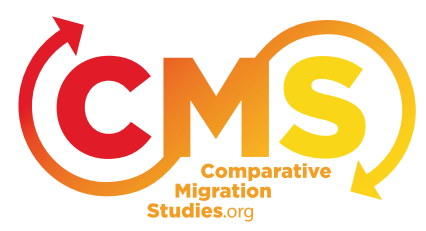

\title{
Venue-Shopping and the Role of Non-governmental Organisations in the Development of the European Union Asylum Policy
}

\author{
Christian Kaunert, Sarah Léonard \& Ulrike Hoffmann
}

\author{
CMS 1 (1): 179-200 \\ DOI: 10.5117/CMS2013.1.KAUN
}

\begin{abstract}
The development of cooperation on asylum and migration matters in the European Union (EU) has often been explained as the result of 'venue-shopping', that is, the move by national policy-makers to a new EU policy venue in order to circumvent domestic obstacles. However, focusing on the case of asylum, recent literature has argued that, contrary to expectations, the move to the EU policy venue has actually resulted in a rise in asylum standards overall. This can be explained by a series of treaty changes that have resulted in the increasing 'communautarisation' and 'judicialisation' of the EU asylum policy venue. This article seeks to further contribute to these debates by examining the hitherto neglected role of refugee-assisting non-governmental organisations (NGOs) in this process. It argues that, contrary to the expectation that venue-shopping to the EU level would enable policy-makers to free themselves from NGO monitoring, NGOs have actually increasingly organised their advocacy work at the EU level in recent years. The treaty changes to the EU asylum policy venue have also increased advocacy opportunities for NGOs, which have enabled them to exercise a significant level of influence over the EU asylum policymaking process, especially at the policy drafting stage. It can be concluded that the current configuration of the EU asylum policy venue offers more opportunities for NGOs to exercise their influence on the development of the EU asylum policy than ever before.
\end{abstract}

Keywords: Advocacy, Asylum, EU asylum policy, Lobbying, Non-governmental organisations, Qualification Directive, Recast Qualification Directive, Venueshopping 


\section{Introduction}

Following the entry into force of the Treaty of Amsterdam in 1999, asylum has become a particularly dynamic policy area in the European Union (EU) (Peers and Rogers, 2006; Ferguson Sidorenko, 2007; Kaunert, 2009, 2010). However, this intensified EU cooperation on asylum matters has been widely criticised. Many scholars have argued that it has led to the gradual establishment of a 'fortress Europe' that does not fully respect the human rights of asylum-seekers and migrants (Ireland, 1991; Joly, 1996; Brouwer and Catz, 2003; Levy, 2005; Baldaccini and Guild, 2007; Chebel d'Appollonia and Reich, 2008; Guild, 2004, 2006, 2009). Some scholars have explained this trend using securitization theory - in their view, asylum and migration have been 'securitized', that is, socially constructed as security threats to the EU (Huysmans, 2000, 2006; Guild, 2003; Colman, 2006; Chebel d'Apollonia and Reich, 2008; Van Munster, 2009).

Another popular explanation of this restrictive trend has been developed by Guiraudon using the concept of 'venue-shopping' (2000). 'Venueshopping' refers to the idea that policy-makers who encounter obstacles in their traditional policy venue generally seek new venues for policy-making that are more amenable to their preferences and goals. Thus, Guiraudon has argued that national officials began to cooperate on asylum and migration matters at the EU level in a bid to circumvent the domestic obstacles that they encountered when attempting to strengthen migration controls at the beginning of the 1980s (Guiraudon, 2000: 252). More precisely, venueshopping to the EU level enabled domestic policy-makers to circumvent three types of obstacles that jeopardised the success of their attempts at increasing migration controls, namely judicial constraints, other more 'migrant-friendly' political actors, and pro-migrant non-governmental organisations (NGOs). In a recent article focusing on the EU asylum policy, Kaunert and Léonard (2012) have revisited the venue-shopping argument. They have concluded that the EU asylum policy venue has significantly changed compared to its configuration at the time of its analysis by Guiraudon. The twin processes of 'communautarisation' and 'judicialisation' of asylum have meant that, overall, asylum standards in the EU have actually been raised, rather than made more restrictive - a view shared by other scholars such as Hailbronner (2008) and El-Enany and Thielemann (2011). However, their article did not consider the aforementioned third obstacle that, according to Guiraudon, national policy-makers were endeavouring to escape when venue-shopping to the EU level, namely NGOs advocating the reinforcement of the rights of asylum-seekers and migrants. The role of 
NGOs in the development of the EU asylum and migration policy was not considered by the rest of the literature on venue-shopping either (Lavenex, 2006; Lahav and Guiraudon, 2006; Maurer and Parkes, 2007). This is precisely the gap that this article seeks to address with a particular focus on the issue of asylum. How have refugee-assisting NGOs responded to the venueshopping of the national governments to the EU level? More precisely, to what extent have they organised themselves at the EU level and managed to influence the development of the EU asylum policy?

For this purpose, this article is structured as follows. Firstly, it discusses the concept of venue-shopping and its application to the development of EU cooperation on asylum and migration matters, before developing an amended venue-shopping framework to be applied to the EU asylum policy. The following section examines the impact that venue-shopping to the EU level and the subsequent changes made to the EU asylum policy venue have had on the activities of refugee-assisting NGOs. It shows that, overall, the switch to an EU venue for asylum policy-making has led to an increase in NGO organisation at the EU level. The third section turns to the important question of the actual influence of the refugee-assisting NGOs on the EU asylum policy, as presence does not necessarily equate with influence at the EU level. This question is addressed by examining the influence of the NGOs on the adoption of two key directives on asylum, namely the so-called 'Qualification Directive' and 'recast Qualification Directive'.

\section{Venue-shopping and the EU Asylum and Migration Policy}

The venue-shopping approach to the study of the EU asylum and migration policy was originally developed by Guiraudon (2000), who drew upon the work by Baumgartner and Jones on 'policy venues'. 'Venue-shopping' refers to the idea that policy-makers seek to avoid obstacles to the realisation of their policy preferences by looking for new policy venues that appear more favourable to the attainment of their goals. On that basis, Guiraudon (2000: 252) has argued that policy-makers in charge of asylum and migration matters venue-shopped to the European level in the 1980 s because they faced domestic opposition to their attempts at increasing migration controls. The domestic obstacles that they encountered notably took the form of judicial constraints, namely the jurisprudence of higher courts - a phenomenon often referred to as the 'judicialisation' of asylum and migration policies (Gibney, 2001). Interior Ministers also found themselves obliged 
to compromise with other ministries, including Labour and Social Affairs, when making national legislation (Guiraudon, 2000; Lahav and Guiraudon, 2006; see also Joppke, 1998, 2001; Joppke and Marzal, 2004; Freeman, 1995, 2006), in addition to seeing their work being monitored by NGOs advocating for the rights of migrants and asylum-seekers.

Guiraudon (2000) argues that, against this backdrop, venue-shopping to the EU level enabled domestic policy-makers to circumvent those obstacles that jeopardised the success of their attempts at increasing migration controls. First of all, venue-shopping allowed policy-makers to avoid judicial constraints, as the European Court of Justice (ECJ) had virtually no competence to adjudicate on asylum and migration matters under the Treaty of Maastricht (1993) and was only given limited competences in this policy area by the Treaty of Amsterdam (1999). In addition, venue-shopping to the EU level enabled Interior ministries to largely exclude 'migrant-friendly' actors such as the European Commission and the European Parliament from the decision-making process. This was because asylum and migration policies were included in the separate Justice and Home Affairs 'Third Pillar', which was largely intergovernmental and significantly limited the role of the EU supranational institutions. In so doing, asylum and migration matters were further decoupled from related issues, such as employment and social affairs, which were part of the European Community 'First Pillar'. Finally, the switch to the EU policy venue had the perceived advantage of making it more difficult for NGOs to monitor policy-making on asylum and migration, as these organisations had been hitherto organised primarily at the national level. According to Guiraudon (2000: 264), at the end of the 1990s, '[m] igrant aid organizations [... had] difficulty in trying to supervise transgovernmental policy-making'. In her view, there was no "'transnational activist network" equivalent to EU lobbies in other fields such as the environment', notably because of a significant lack of resources (Guiraudon, 2000: 264).

For the purpose of this article, several modifications have been made to the venue-shopping framework as it was developed and applied by Guiraudon (2000). First of all, it is argued that it is necessary to distinguish between the issues of asylum, migration and borders. Although they are related, they have not always been governed on the basis of the same institutional arrangements. In addition, the EU treaties clearly indicate that policy-makers seek to achieve different goals with respect to each of them (Kaunert and Léonard, 2012). As a result, it can be argued that, in practice, asylum, migration and borders are each dealt with in a distinct policy venue, which can be analytically separated from the others. The present 
article focuses on the EU asylum policy and, consequently, the EU asylum policy venue. The EU has defined the goal of its 'common policy on asylum, subsidiary protection and temporary protection' as 'offering appropriate status to any third-country national requiring international protection and ensuring compliance with the principle of 'non-refoulement' (Article 78 of the Treaty on the Functioning of the European Union (TFEU)).

Secondly, this article advocates a more dynamic approach to venueshopping by analysing the development of a policy venue over time, rather than providing a snapshot of this venue at a given time. This is necessary when analysing any EU policy, given the important modifications that have been introduced by the various EU treaties over the years, in particular the Treaty of Amsterdam (1999) and the Treaty of Lisbon (2009). As already suggested by Baumgartner and Jones (2009: 216), changes to a policy venue may have a significant impact on the behaviour of the actors concerned. In the literature on the EU, this idea has been confirmed by studies on the influence of the gradual extension of co-decision to a growing number of policies over the behaviour of Members of the European Parliaments (MEPs), such as Ripoll Servent's works $(2012,2013)$ on various aspects of the Area of Freedom, Security and Justice (AFSJ). Thus, for example, the entry into force of the Treaty of Lisbon in December 2009 has led to changes in the competences and relative power positions of the various actors in the EU asylum policy venue. Such modifications may have affected the preferences and behaviour of the actors concerned, which in turn may have had a significant impact on policy outcomes. It is therefore necessary to consider the evolution of any given policy venue over time.

Thirdly, this article adopts a different approach than Guiraudon's to the preferences of the Member States. More precisely, it does not assume that the EU Member States use venue-shopping to pursue restrictive asylum and migration policies. The ideas that all 28 Member States would share the same preference for restrictive asylum policies and that this would remain constant over time are put into question. There are two main reasons for doing so. First of all, Western states generally do not pursue unequivocally restrictive asylum and migration policies. This is aptly illustrated by former French President Sarkozy's call for 'immigration choisie' rather than 'immigration subie' (Bonjour, 2011: 91). For a variety of reasons, including the existence of pull-factors in the destination states, Western states accept 'unwanted migration' (Joppke, 1998). As a result, there is a migration control gap, since the goals and the actual outputs of national migration policies do not coincide (Cornelius, Martin and Hollifield, 1994). In light of this literature, it could therefore be an over-simplification to assume that all 
EU Member States consistently pursue the adoption of restrictive asylum and migration measures. Moreover, given that EU cooperation on asylum has developed over time, it can be argued that national interests are at least partly the result of international cooperation (see Katzenstein, 1996). Thus, in line with the works of scholars such as Haas (1958) and Sandholz (1993), preference formation can be regarded as endogenous of institutionalised cooperation, that is, partly resulting from the cooperation itself. As a result, it is likely to see the preferences of the Member States over asylum evolve at least partially over time as a result of their cooperation within the EU institutional context. This also means that venue-shopping is not a risk-free strategy. Actors who decide to venue-shop may encounter unanticipated obstacles, such as changes in the preferences of the other actors involved or the appearance of new actors in the new venue with different, perhaps even opposite, policy preferences.

Having developed an amended venue-shopping framework, it is now possible to consider the impact of venue-shopping to the EU level on refugeeassisting NGOs. First of all, the article will consider the extent to and the ways in which venue-shopping in the area of asylum had led the NGOs to organise their work at the EU level. The following section will consider the extent to which the NGOs have been able to influence the development of the EU asylum policy, using the cases of two key directives on asylum, namely the so-called 'Qualification Directive' and 'recast Qualification Directive'.

\section{The Impact of Venue-shopping to the EU Level on Refugee-assisting NGOs}

According to Guiraudon (2000), the growth in European cooperation on asylum matters in the 1980s and 1990s was not initially matched by the development of monitoring of these activities by refugee-assisting NGOs. This is not to say that there was no transnational cooperation amongst NGOs advocating for the rights of refugees at the time (Niessen, 2002). Actually, the oecumenical Churches' Commission for Migrants in Europe (CCME) was established as early as 1964, whilst the European Council on Refugees and Exiles (ECRE), which is a pan-European alliance of NGOs assisting refugees, was founded in 1974. However, initially, these organisations found it generally difficult to monitor the development of European asylum cooperation. This was due to several factors, including a relative lack of resources and the secrecy surrounding European asylum cooperation, both outside and 
subsequently inside the framework of the EU following the entry into force of the Treaty of Maastricht.

However, the growing cooperation on asylum matters in Europe has led to significant changes in the political opportunity structures for groups advocating the attribution of higher protection standards and extended rights to asylum-seekers. From a policy venue largely dominated by the Member States - and more precisely, their Interior Ministers - under the Treaty of Maastricht, the EU asylum policy venue has gradually evolved into a policy venue where EU supranational institutions matter. This is important for refugee-assisting NGOs, as an increase in the number of actors involved entails an increase in their opportunities for advocacy. The EU asylum policy venue has evolved as a result of the changes introduced by the various EU Treaties. Under the Treaty of Maastricht, Member States largely dominated the asylum policy venue. The European Commission was only 'fully associated with the work' in the area of asylum, whilst the role of the European Parliament was limited to being informed and consulted on the initiatives of the Member States. As for the ECJ, it had virtually no role with respect to EU asylum provisions (Article K of the Treaty of Maastricht). These institutional arrangements were significantly changed by the Treaty of Amsterdam, which entered into force in 1999. The role of the European Commission was reinforced as it received the competence to draft proposals on various aspects of the EU asylum policy. However, during a transitional period of five years, it had to share its right of initiative with the Member States. During this period, the Council took decisions unanimously after consulting the European Parliament. The Treaty of Amsterdam also gave the ECJ a more prominent role in the EU asylum policy venue (Article 73(p) of the Treaty of Amsterdam). Finally, the Treaty of Lisbon, which entered into force on 1 December 2009, further strengthened the role of the European Parliament and of the ECJ respectively. First of all, it foresees that all asylum legal instruments should be adopted in accordance with the ordinary legislative procedure, which is laid down in Article 294 TFEU. This means that the European Parliament has now acquired joint decision-making powers on asylum, which represents a significant increase in power for this institution compared to previous institutional arrangements, whilst the Council takes decisions by qualified majority voting. In addition, judicial control has been expanded, as the Court's ${ }^{1}$ role has been strengthened with respect to the AFSJ, including the EU asylum policy. In particular, the Court's preliminary jurisdiction, which used to be limited, has been expanded and generalised to all AFSJ matters by the Treaty of Lisbon, with respect to both primary and secondary law. Thus, 
the various treaty changes over the years have led to a diversification of the actors involved in the EU asylum policy venue and the strengthening of the EU institutions traditionally seen as more 'friendly' towards migrants and asylum-seekers, such as the European Commission, the European Parliament and the Court (Guiraudon, 200o). As a result, refugee-assisting NGOs now have more advocacy opportunities than a few years ago.

Nevertheless, despite this gradual expansion of advocacy opportunities, not all refugee-assisting groups are able or willing to engage with EU policy-makers. Grass-root movements generally refrain from including the EU institutions in their advocacy strategy. This is mainly due to the fact that their organisational structure, main arguments and activities do not fit the EU procedures and the needs of the EU institutions (Danese, 1998; Geddes, 1998; Gray and Statham, 2005; Guiraudon, 2001; Monforte, 2009). Grass-root movements are mainly oriented towards mobilising public opinion through demonstrations and petitions. Their claims are politicised and framed according to the national context in which they operate. Furthermore, these groups mainly rely on their activist base and therefore lack an appropriate organisational structure. In contrast, for an organisation to efficiently operate at the EU level, it requires the capacity to monitor the whole policy process. Only groups that employ asylum experts and have established a secretariat in Brussels are able to liaise continuously with EU policy-makers and closely follow the development of policy initiatives. By the same token, transnational networks or umbrella groups with members in different EU Member States are more likely to provide the EU institutions with the information that those need for drafting European solutions to asylum issues. As a consequence, as will be shown in greater detail in the next section, rather than national grass-root movements, the organisations that operate at the EU level are professionalised lobby groups, international NGOs and European umbrella groups of national associations (Interviews $1,7,8,9,10,11,17,20,23,28,29)$. The establishment of these groups has actually been promoted and subsidised by the European Commission and the European Parliament, as they considered that European integration could not ignore the issue of the integration of non-EU citizens. The European Commission and the European Parliament also saw the help that these NGOs could give them to devise European solutions to asylum problems and challenges, thereby strengthening their own position in the EU asylum policy venue (Geddes, 1998, 2000; Guiraudon, 2001). In that respect, the expertise offered by the NGOs ranges from legal advice on the interpretation of international conventions and case law to 'on-the-ground' information 
about national asylum practices and obstacles to the implementation of EU asylum legislation.

Thus, it can be concluded that venue-shopping to the EU level and the subsequent changes to the composition of the EU asylum policy venue have led to an increase in advocacy opportunities for refugee-assisting NGOs. Those have increasingly organised their activities at the EU level, although it should be remembered that some important initiatives, such as the establishment of ECRE, actually pre-date venue-shopping to the EU level. Having considered the impact of venue-shopping to the EU level on the refugee-assisting NGOs and the organisation of their activities, it is also important to consider the extent to and the ways in which these NGOs have been able to exercise any influence on the development of the EU asylum policy.

\section{The Influence of Refugee-assisting NGOs on the Development of the EU Asylum Policy}

Given the space constraints inherent to this article, it is not possible to examine here all the asylum provisions that have been adopted by the EU. In order to analyse the possible influence of refugee-assisting NGOs on the development of the EU asylum policy, it is therefore suggested to focus on two key asylum directives, namely the Qualification Directive and the recast Qualification Directive. The Qualification Directive (Council Directive 2004/83/EC) set standards for identifying people in need of international protection in the EU either as refugees or as beneficiaries of subsidiary protection, as well as laying down a minimum level of benefits and rights for both categories of beneficiaries of international protection throughout the EU. However, a comprehensive impact assessment of its implementation by the Member States concluded that there was further need for approximating the grounds for and the content of international protection. As a consequence, the European Commission opened a recast procedure that led to the adoption of the recast Qualification Directive in December 2011 (Directive 2011/95/EU of the European Parliament and of the Council). This directive further raised asylum standards in the EU by introducing several changes, including the clarification of various concepts through the incorporation of recent case-law of the Court of Justice of the EU and of the European Court of Human Rights, measures to better take into account gender-related issues and children's interests in asylum assessment processes, the approximation of the rights granted to refugees and benefi- 
ciaries of subsidiary protection relating to health care and employment, as well as the extension of the period of validity of residence permits issued to beneficiaries of subsidiary protection in some circumstances.

These two directives have been chosen amongst the various asylum directives adopted in recent years for two main reasons. First of all, the Qualification Directive and its recast are arguably the most important components of the CEAS. They clarify the criteria for granting international protection - a fundamental aspect of international protection, which supersedes the matters such as temporary protection, asylum procedures and reception conditions that are the object of the other directives. Moreover, the selection of two directives dealing with the same subject, but adopted under different treaty arrangements, allows for the analysis of the impact of the changes made to the decision-making procedures in the asylum policy venue over time.

The remainder of this section investigates the influence of refugeeassisting NGOs on the development of the EU asylum policy, contrasting the case of the Qualification Directive with that of the recast Qualification Directive. In that way, it is possible to highlight the possible impact of the changes made to the asylum policy venue on the activities and influence of the NGOs. However, before proceeding further, it is necessary to first elaborate upon the methodology used.

\subsection{Analysing the Lobbying Strategies of Refugee-assisting NGOs and their Influence over the Qualification Directive and the recast Qualification Directive}

Assessing the lobbying strategies and the influence of interest groups such as refugee-assisting NGOs is a complex task, as those cannot be directly observed. Some methodological observations are therefore in order. First of all, for the purpose of this article, influence is understood as the capability of a refugee-assisting NGO to modify the behaviour of another EU actor through distributing policy papers and liaising with EU decision-makers. In addition, the following methodology was used to evaluate the influence of the refugee-assisting NGOs. Firstly, their goal achievement was analysed, by systematically comparing their position papers with the official documents emanating from the EU institutions as part of the policy-making process. To what extent were the recommendations made by the NGOs reflected in the EU official documents? Although it is possible to provide percentages of the recommendations of the NGOs that also appear in the official documents, the present article does not provide such figures, but rather a qualitative assessment. A less mechanistic assessment is arguably more suitable, since 
not all provisions have the same significance and impact on the asylum systems of the Member States. The issue of persecution by non-state actors, which has led to considerable changes in the national legislation of several EU Member States, including France and Germany, is a case in point (El- Enany and Thielemann, 2011: 106-107). Nevertheless, the existence of congruence between the positions of a given refugee-assisting $\mathrm{NGO}$ and an EU institution does not necessarily constitute evidence of successful lobbying of this institution on the part of the NGO. The EU institution may have held this position prior to or independently from the lobbying of the NGO. Furthermore, many of the recommendations made by the refugee-assisting NGOs reflect existing instruments, such as the Geneva Convention relating to the Status of Refugees, which is binding on its signatories, guidelines produced by the UNHCR that advise the states and the EU institutions on asylum matters, as well as recent case law by the Court of Justice of the EU and the European Court of Human Rights. Congruence between an EU official document and a position paper published by an NGO may therefore have been more prompted by the existence of these standards than by the lobbying work of the NGOs. In order to address this problem, a second step in the analysis consisted of establishing the influence that is attributed to the refugee-assisting NGOs. This was done by asking the representatives of the various refugee-assisting NGOs to conduct a self-assessment of their influence, whereas officials from the EU institutions were asked to peer-assess the influence of the NGOs. Concerning the methods used, the research results that are presented in this article are based on exhaustive documentary analysis and semi-structured expert interviews. The European Commission's online consultation on the 'Future of the Common European Asylum System' (Commission of the European Communities, 2007) constituted the starting point of the sampling exercise, followed by snowballing sampling to identify further interest groups and position papers. In total, eight pro-migrant groups confirmed that they had actively lobbied on the two directives. As a result, 30 interviews were conducted with interest representatives and EU officials.

\subsection{Refugee-assisting NGOS and the EU Asylum Policy under the Treaty of Amsterdam: The Case of the Qualification Directive}

Concerning the original Qualification Directive, which was adopted under the Treaty of Amsterdam, ECRE, the Amnesty International European Institutions Office (AI Europe), and various organisations gathered in the 'Churches and Christian Organisations in Europe on Migration and Asylum' 
(CCOEMA) network - namely Caritas Europa, CCME, the Commission of the Bishops' Conferences of the EC, the International Catholic Migration Commission, the Jesuit Refugee Service-Europe, and the Quaker Council for European Affairs - actively tried to lobby the Council (AI Europe, 2001a, 2001b, 2002a, 2002 b, 2003; CCOEMA, 2002; ECRE, 2001; Khan, 2001). ECRE was the only group that lobbied both the Council and the European Commission during the drafting stage of the Qualification Directive proposal (ECRE, 2000a, 200ob). No refugee-assisting NGO appears to have developed any lobbying strategy towards the European Parliament at the time.

With regard to goal achievement, at the drafting stage, ECRE was fairly successful. Its recommendations and the Commission's proposal for the Qualification Directive especially concur on the general provisions and the chapter that defines the qualification criteria for international protection, such as the provision concerning non-state actor persecution. However, one observes less congruence between the positions of the refugee-assisting NGOs and those of the Council. Less than half - and even, in the case of some NGOs, less than a third - of the recommendations put forward by refugee-assisting NGOS were reflected in the Council's positions. The NGOs were particularly unsuccessful when it came to the chapter determining the content of international protection, especially on the issue of the unequal treatment of refugees and beneficiaries of subsidiary protection with regard to the validity of residence permits, access to travel documents, employment, and integration facilities.

While most of the interest representatives that were interviewed on the influence of their group remained rather modest about their lobbying success on the Qualification Directive, a representative of ECRE distinguished between the level of influence over the European Commission and that over the Council. According to him, many of the recommendations made by ECRE were reflected in the proposal of the European Commission, but were not adopted by the Member States (Interviews 1, 8, 11, 20, 28). Confirming the impression of the representative of ECRE, the Commission official in charge of drafting the proposal for the directive admitted that the European Commission 'benefited from the expertise and input of this kind of think tanks because they were badly needed' (Interview 3). Further reflecting the self-assessment of the NGOs, the rapporteur for the Qualification Directive proposal in the European Parliament and a member of the Council General Secretariat assessed the impact of the NGOs over the Council as being marginal (Interviews 2 and 16). 


\subsection{Refugee-assisting NGOS and the EU Asylum Policy under the Treaty of Lisbon: The Case of the recast Qualification Directive}

In the case of the recast Qualification Directive, in total eight pro-migrant groups were involved in the lobbying of the EU institutions. Five groups tried to influence the drafting of the proposal by the European Commission - AI Europe (2007), the CCOEMA network (2007), ECRE (2007), the European Women's Lobby (EWL) (2007), and the Red Cross (2007). At the decisionmaking stage, the European Parliament and the Council were lobbied by the CCOMEA network (2010), ECRE (2009, 2010a, 2010b, 2010c, 2010d, 2011), Terre des Hommes (TdH 2009), EWL, Asylum Aid, and the European Region of the International Lesbian, Gay, Bisexual, Trans and Intersex Association (EWL, Asylum Aid, ILGA 2010), as well as the Red Cross (2010).

The analysis of the goal achievement of the NGOs shows that the vast majority of the provisions that they suggested were reflected in the proposal of the European Commission. This was particularly the case when it came to the establishment of one single protection status with regard to rights, such as family unity, residence permit, travel documents, employment, education, recognition of qualifications, social welfare, health care, accommodation, free movement, and integration facilities. In contrast, only about half of the recommendations made by the refugee-assisting NGOs were reflected in the positions adopted by the Council and the European Parliament.

Concerning the assessment of their influence, representatives of AI Europe and the Red Cross expressed scepticism as to their ability to having exerted significant influence on the outcome of the recast Qualification Directive negotiations (Interviews 9 and 20). Representatives of the organisations gathered in the CCOEMA network also remained modest about their influence on the directive. They expressed their disappointment about the fact that the subsidiary protection status had not been fully aligned on the refugee status by the new directive (Interviews 1 and 11). In contrast, representatives of EWL, ILGA, and Asylum Aid were considerably more positive about their influence on both the European Commission and the European Parliament, notably with respect to the inclusion of the concept of gender identity. Nevertheless they regretted not having been able to convince the Council on other provisions, such as the extension of the definition of family (Interviews 10, 23, 29). A representative of ECRE made a similar distinction. While she generally saw 'no political willingness within the states for this legislation at the moment', she considered ECRE to have been 'quite influential on the approximation of rights for example' 
at the drafting stage (Interview 17). Finally, a former representative of TdH declared his satisfaction as to the outcome of the recast Qualification Directive. However, he also emphasised that, at the same time, he believed that the overall influence of $\mathrm{TdH}$ had been limited (Interview 5).

Concerning the peer-assessment of the influence of the NGOs, the Commission official responsible for drafting the recast Qualification Directive confirmed the impression of several NGO representatives when she acknowledged that 'some things for sure were integrated after discussions with NGOs but also filtered in order to fit the logic of the whole text' (Interview 18). The assessment of the European Parliament was different, as the rapporteur and shadow rapporteurs for the recast Qualification Directive held significantly different views. While some of them considered that refugee-assisting NGOs had exercised medium influence on the directive, others considered their impact on the policy-making process negligible (Interviews 16, 19, 22, 27, 30). For some Justice and Home Affairs Councillors, refugee-assisting NGOs exercised influence over the European Commission and the European Parliament, but not over the Council (Interviews 2, 4, 6, $12,13,14,15,21,24,25,26)$.

\subsection{Refugee-assisting NGOs and the Changing Character of the EU Asylum Policy Venue}

The comparison of the behaviour of refugee-assisting NGOs towards the EU institutions under the Treaties of Amsterdam and Lisbon has highlighted several important points. First of all, it is evident that there has been a significant increase in the number of groups actively seeking to influence the development of the EU asylum policy in recent years. Secondly, since the entry into force of the Treaty of Amsterdam, the European Commission has emerged as a key actor to be lobbied by the NGOs. It is perceived as both playing a pivotal role, given its right of initiative (which has become a sole right of initiative since 2004), and being generally open and responsive to the demands of the refugee-assisting groups (Interviews 1, 7, 8, 19, 11, $17,20)$. This is markedly different from the situation under the Treaty of Maastricht where the Justice and Home Affairs Taskforce, which preceded the first Justice and Home Affairs Directorate-General in the Commission, had the reputation of not interacting with the NGOs (Guiraudon, 2000: 263). However, some NGO representatives were of the opinion that the European Commission had recently become less responsive to their claims than before, because it sensed some reluctance amongst the Member States towards more progressive and liberal provisions and sought not to antagonise them (Interviews 10 and 23). Thirdly, the European Parliament 
has been generally perceived as an accessible institution (Interviews 1, 2, $9,10,11,17,20,23$ ), which has also had the reputation of being a 'friend of third country nationals' since the 1970s (Guiraudon, 2000: 264). However, under the Treaty of Amsterdam, it was not viewed as a priority institution for lobbying by the NGOs, because it was only consulted as part of the policy-making process - and, thereby, largely ignored in practice. This considerably changed with the entry into force of the Treaty of Lisbon, which has transformed the European Parliament into a co-legislator on asylum matters (Interviews 1, 20). The European Parliament is now another key-target for lobbying by the refugee-assisting NGOs. However, some NGO representatives mentioned that MEPs are not as supportive of their progressive recommendations as they were under the Treaty of Amsterdam. They appear to be more concerned than before about matters of cost and feasibility (Interviews 1 and 29). This observation chimes with the works of Acosta (2009) and Ripoll Servent $(2011,2012,2013)$ who have observed similar shifts in the positions of the European Parliament on other aspects of the AFSJ. Fourthly, since the days of the Treaty of Maastricht, the Council has been seen as a powerful policy-maker. However, it continues to be perceived as significantly less accessible and less responsive towards the ideas of the refugee-assisting NGOs. Above all, interest representatives complain about the opaque internal structure and procedures that make approaching the General Secretariat of the Council extremely difficult. They therefore tend to focus their advocacy work on the Permanent Representations of the Member States, the rotating EU Presidencies, and national ministries (Interviews 1, 5, 7, 8, 9, 10, 11, 17, 20, 23, 28, 29).

\section{Conclusion}

This article aimed to contribute to the scholarly debates on venue-shopping and the EU asylum policy by examining the hitherto neglected role of refugee-assisting NGOs in this process. It has demonstrated that, contrary to the expectation that venue-shopping to the EU level would enable policymakers to free themselves from NGO monitoring, NGOs have actually increasingly organised their advocacy work at the EU level in recent years. The treaty changes to the EU asylum policy venue have also increased advocacy opportunities for NGOs. This has enabled them to exercise a significant level of influence over the EU asylum policy-making process, especially at the policy drafting stage. Thus, this article has further refined the argument put forward by Kaunert and Léonard (2012) by highlighting how the more 
progressive preferences of the more 'refugee-friendly' institutions such as the European Commission and the European Parliament have been at least partially shaped and influenced by the lobbying of refugee-assisting NGOs.

Finally, the article has also confirmed the importance of considering the evolution of policy venues over time in any analysis of venue-shopping, as advocated in the theoretical section of this article. The comparison of the NGOs' attempts at influencing EU institutions in the cases of the Qualification Directive and the recast Qualification Directive has demonstrated that the institutional arrangements governing a policy venue have a significant impact on the preferences and behaviours of the actors concerned. It has been demonstrated that the gradual reinforcement of the powers of the European Commission and the European Parliament has been accompanied by a certain move away from their initially more generous and liberal asylum positions. However, it is important to emphasise that they continue to promote significantly less restrictive positions than the Council. In other words, compared to the pre-2004 situation, refugee-assisting NGOs now benefit from more advocacy opportunities, whilst the powers of the more refugee-friendly institutions have also been enhanced. This means that, overall, even if the positions of the European Commission and the European Parliament may be slightly less liberal or inclusive than they were before, the current configuration of the EU asylum policy venue offers significant opportunities for NGOs to influence the content of EU asylum policy and thus co-determine the general framework within which national asylum policies are formulated.

\section{Note}

1. Since the entry into force of the Treaty of Lisbon, the EU's judicial authority has been called the 'Court of Justice of the European Union' and consists of the 'Court of Justice' and the 'General Court'.

\section{References}

Acosta, D. (2009) 'The Good, the Bad and the Ugly in EU Migration Law: Is the European Parliament Becoming Bad and Ugly? (The Adoption of Directive 2008/15: The Returns Directive)'. European Journal of Migration and Law, 11: 19-39.

AI Europe (2001a) Security and Refugee Protection: Amnesty International's Comments on the relationship between safeguarding internal security and complying with international obligations of protection towards refugees and asylum-seekers. Brussels.

AI Europe (2001b) The Asylum Crisis: A Human Rights Challenge for the EU. Brussels. 
AI Europe (2002a) Amnesty International's concerns regarding the discussion paper issued by the Danish Presidency concerning recognition rates on Convention refugees and persons in need of protection in Member States and (the road towards) a common understanding of international protection. Brussels.

AI Europe (2002b) Amnesty International's Comments on the Commission's Proposal for a Council Directive on Minimum Standards for the Qualification and Status of Third Country National and Stateless Persons as Refugees or as Persons Who Are Otherwise in Need of International Protection, COM (2001) 510 final. Brussels.

AI Europe (2003) Amnesty International's Comments on Articles 20-32 of the Commission's Proposal for a Council Directive on Minimum Standards for the Qualification and Status of Third Country Nationals and Stateless Persons as Refugees or as Persons Who Are Otherwise in Need of International Protection, COM (2001), 510 final. Brussels.

AI Europe (2007) Response to the European Commission's Green Paper on the future of the Common European Asylum System - COM (2007) 301 final. Brussels.

Baldaccini, A. and Guild, E. (eds) (2007) Terrorism and the Foreigner: A Decade of Tension around the Rule of Law in Europe. Leiden: Martinus Nijhoff.

Baumgartner, F.R. and Jones, B.D. (2009) Agendas and Instability in American Politics, $2^{\text {nd }}$ ed. Chicago, IL: University of Chicago Press.

Bonjour, S. (2011) 'The Power and Morals of Policy Makers: Reassessing the Control Gap Debate'. International Migration Review, 45(1): 89-122.

Brouwer, E. and Catz, P. (2003) 'Terrorism and the Struggle for Competence in Community Law'. In: Brouwer, E., Catz, P. and Guild, E. (eds) Immigration, Asylum and Terrorism: A Changing Dynamic in European law. Nijmegen: Instituut voor Rechtssociologie/Centrum voor Migratierecht, KU Nijmegen.

CCOEMA (2002) Joint comments on the Commission Proposal for a Council Directive on minimum standards for the qualification and status of third country nationals and stateless persons as refugees, or as persons who otherwise need international protection $\mathrm{COM}$ (2001) 510 final. Brussels.

CCOEMA (2007) Comments on the European Commission's Green Paper on the future Common European Asylum System COM (2007) 301 final. Brussels.

CCOEMA (2010) Comments on the proposed recasts of Directive 2004/83/EC (Qualification Directive) and Directive 2005/85/EC (Asylum Procedures Directive). Brussels.

Chebel d'Appollonia, A. and Reich, S. (eds) (2008) Immigration, Integration, and Security: America and Europe in Comparative Perspective. Pittsburgh, PA: University of Pittsburgh Press.

Colman, N. (2006). 'From Gulf War to Gulf War: Years of Security Concern in Immigration and Asylum Policies at EU Level'. In: Baldaccini, A. and Guild, E. (eds) Terrorism and the Foreigner: A Decade of Tension around the Rule of Law in Europe. Leiden: Martinus Nijhoff.

Commission of the European Communities (2007) Green Paper on the future Common European Asylum System. Brussels.

Cornelius, W.A., Martin, P.L. and Hollifield, J.F. (1994) 'Introduction: The Ambivalent Quest for Immigration Control'. In: Cornelius, W.A., Martin, P.L. and Hollifield, J.F. (eds) Controlling Immigration: A Global Perspective. Stanford, CA: Stanford University Press: 3-41.

Danese, G. (1998) 'Transnational Collective Action in Europe: The Case of Migrants in Italy and Spain'. Journal of Ethnic and Migration Studies, 24(4): 715-733.

ECRE (2000a) Position on complementary protection. Brussels.

ECRE (200ob) Position on the interpretation of Article 1 of the Refugee Convention. Brussels.

ECRE (2001) Comments from the European Council on Refugees and Exiles on the proposal for a Council Directive on minimum standards for the qualification and status of third country 
nationals and stateless persons as refugees or as persons who otherwise need international protection. Brussels.

ECRE (2007) Submission from the European Council on Refugees and Exiles in response to the Commission's Green Paper on the Future Common European Asylum System (COM (2007) 301). Brussels.

ECRE (2009) Memorandum on the occasion of the Spanish Presidency (January 2010- June 2010). Brussels.

ECRE (2010a) Briefing on amendments tabled in the European Parliament LIBE Committee to the Commission proposal recasting the Qualification Directive (COM(2009) 551final). Brussels.

ECRE (2010b) Comments from the European Council on Refugees and Exiles on the European Commission Proposal to recast the Qualification Directive. Brussels.

ECRE (2010c) ECRE Memorandum on the occasion of the Belgian Presidency of the EU (July December 2010). Brussels.

ECRE (2010d) Promote the inclusion of refugees and asylum seekers into labour market. Brussels.

ECRE (2011) ECRE Memorandum on the Occasion of the Hungarian Presidency of the EU (January - June 2011). Brussels.

El-Enany, N. and Thielemann, E. (2011) 'The Impact of EU Asylum Policy on National Asylum Regimes'. In:Wolff, S. et al. (eds) Freedom, Security and Justice after Lisbon and Stockholm, The Hague: T.M.C. Asser Press.

European Women's Lobby (2007) Contribution from the European Women's Lobby to the European Commission's Green Paper on the future Common Asylum System COM (2007) 301 final. Brussels.

European Women's Lobby, Asylum Aid, and ILGA Europe (2010) Proposal for amendments on the Commission's proposal for a Directive of the European Parliament and of the Council on minimum standards for the qualification and status of third country nationals or stateless persons as beneficiaries of the international protection and the content of the protection granted (recast). Brussels.

Ferguson Sidorenko, O. (2007) The Common European Asylum System. The Hague: T.M.C. Asser Press.

Freeman, G. (1995) 'Modes of Immigration Politics in Liberal Democratic States'. International Migration Review, 29(4): 881-902.

Freeman, G. (2006) 'National Models, Policy Types and the Politics of Immigration in Liberal Democracies'. West European Politics, 29(2): 227-247.

Geddes, A. (1998) 'The Representation of “Migrants' Interests" in the European Union'. Journal of Ethnic and Migration Studies, 24(4): 695-713.

Geddes, A. (2000) 'Lobbying for Migrant Inclusion in the European Union: New Opportunities for Transnational Advocacy?'. Journal of European Public Policy, 7: 632-649.

Gibney, M.J. (2001) 'The State of Asylum: Democratization, Judicialization and Evolution of Refugee Policy in Europe'. New Issues in Refugee Research Working Paper, No. 50.

Gray, E. and Statham, P. (2005) 'Becoming European? The Transformation of the British Promigrant NGO Sector in Response to Europeanization', Journal for Common Market Studies, 43(4): $877-898$.

Guild, E. (2003) 'International Terrorism and EU Immigration, Asylum and Borders Policy: The Unexpected Victims of 11 September 2001'. European Foreign Affairs Review, 8(3): 331-346.

Guild, E. (2004) 'Seeking Asylum: Stormy Clouds between International Commitments and EU Legislative Measures'. European Law Review 29(2): 198-218.

Guild, E. (2006) 'The Bitter Fruits of a Common Asylum Policy'. In Balzacq, T. and Carrera, S. (eds) Security Versus Freedom? A Challenge for Europe's Future. Aldershot: Ashgate.

Guild, E. (2009) Security and Migration in the 21st Century. Cambridge: Polity. 
Guiraudon, V. (2000) 'European Integration and Migration Policy: Vertical Policy-making as Venue Shopping'. Journal of Common Market Studies, 38(2): 251-271.

Guiraudon, V. (2001) 'Weak Weapons of the Weak? Transnational Mobilization around Migration in the European Union'. In: Imig, D. and Tarrow, S. (eds) Contentious Europeans: Protest and Politics in an emerging Polity. Oxford: Rowman \& Littlefield: 163-183.

Haas, E. (1958) The Uniting of Europe. London: Stevens.

Hailbronner, K. (2008) 'Minimum Standards relating to the Eligibility for Refugee Status or International Protection and Content of these Status - Assessment (Summary) of the Implementation of the 2004 Directive and Proposals for a Common European Regime of Asylum'. European Parliament Briefing Note, No. PE 393.293.

Huysmans, J. (2000) 'The European Union and the Securitization of Migration'. Journal of Common Market Studies, 38(5): 751-777.

Huysmans, J. (2006) The Politics of Insecurity: Fear, Migration and Asylum in the EU. London: Routledge.

Ireland, P. (1991) 'Facing the True "Fortress Europe": Immigrants and Politics in the EC'. Journal of Common Market Studies, 29(5): 457-480.

Joly, D. (1996) Haven or Hell? Asylum Policies and Refugees in Europe. Basingstoke: Macmillan.

Joppke, C. (1998) 'Why Liberal States Accept Unwanted Immigration'. World Politics, 50(2): 266-293.

Joppke, C. (2001) 'The Legal-domestic Sources of Immigrant Rights: The United States, Germany and the European Union'. Comparative Political Studies, 34(4): 339-366.

Joppke, C. and Marzal, E. (2004) 'Courts, the New Constitutionalism and Immigrant Rights: The Case of the French Conseil Constitutionnel'. European Journal of Political Research, 43: $823-844$.

Katzenstein, P. (1996) The Culture of National Security: Norms and Identity in World Politics. New York, NY: Columbia University Press.

Kaunert, C. (2009) 'Liberty versus Security? EU Asylum Policy and the European Commission'. Journal of Contemporary European Research, 5(2): 148-170.

Kaunert, C. (2010) European Internal Security: Towards Supranational Governance in the Area of Freedom, Security and Justice. Manchester: Manchester University Press.

Kaunert, C. and Léonard, S. (2012) 'The Development of the EU Asylum Policy: Venue-shopping in Perspective'. Journal of European Public Policy, 19(9): 1396-1413.

Khan, I. (2001) Open letter to the Heads of State or Government of the European Union - Security and refugee protection: the human rights agenda for the Laeken Summit. An Appeal by Amnesty International. Brussels.

Lahav, G. and Guiraudon, V. (2006) 'Actors and Venues in Immigration Control: Closing the Gap between Policy Demands and Policy Outcomes'. West European Politics, 29(2): 201-223.

Lavenex, S. (2006) 'Shifting Up and Out: The Foreign Policy of European Immigration Control'. West European Politics, 29(2): 329-350.

Levy, C. (2005) 'The European Union after 9/11: the Demise of a Liberal Democratic Asylum Regime?'. Government and Opposition, 40(1): 26-59.

Maurer, A. and Parkes, R. (2007) 'The Prospect for Policy-change in EU Asylum Policy:Venue and Image at the European Level'. European Journal of Migration and Law, 9: 173-205.

Monforte, P. (2009) 'Social Movements and Europeanization Process: The Case of the French Associations Mobilizing around the Asylum Issue'. Social Movement Studies, 8(4): 409-425.

Niessen, J. (2002) 'Consultations on Immigration Policies in the European Union'. European Journal of Migration and Law, 4(1): 79-83.

Peers, S. and Rogers, N. (2006) (eds) EU Asylum and Migration Law: Text and Commentary. Leiden: Martinus Nijhoff. 
Red Cross (2007) European Commission Green Paper on the future Common European Asylum System: Opinion of the National Red Cross Societies of the Member States of the European Union and the International Federation of Red Cross and Red Crescent Societies. Brussels.

Red Cross (2010) Proposal for a Directive on minimum standards for the qualification and status of third country nationals or stateless persons as beneficiaries of international protection and the content of the protection granted (Qualification Directive). Brussels.

Ripoll Servent, A. (2011) 'Co-decision in the European Parliament: Comparing Rationalist and Constructivist Explanations of the Returns Directive'. Journal of Contemporary European Research, $7(1): 3^{-22}$.

Ripoll Servent, A. (2012) 'Playing the Co-Decision Game? Rules' Changes and Institutional Adaptation at the LIBE Committee'. Journal of European Integration, 34(1): 55-73.

Ripoll Servent, A. (2013) 'Holding the European Parliament Responsible: Policy Shift in the Data Retention Directive from Consultation to Codecision'. Journal of European Public Policy, 2o(7): $972-987$.

Sandholz, W. (1993) ‘Choosing Union: Monetary Politics and Maastricht'. International Organization, 47(1): 1-39.

TdH (2009) Position paper on Council Directive 2004/83/EC of 29 April 2004 on minimum standards for the qualification and status of third country nationals or stateless persons as refugees or as persons who otherwise need international protection and the content of the protection granted (Qualification Directive). Brussels.

Van Munster, R. (2009) The Politics of Risk in the European Union: Securitizing Immigration. Basingstoke: Palgrave.

\section{List of Interviews}

Interview 1 conducted with a representative of Caritas Europa on 7 June 2011 in Brussels.

Interview 2 conducted with a member of Council General Secretariat staff on 14 June 2011 in Brussels.

Interview 3 conducted with a Commission desk officer on 21 June 2011 in Brussels.

Interview 4 conducted with a JHA Councillor of the Permanent Representation of Finland to the EU on 21 June 2011 in Brussels.

Interview 5 conducted with a representative of Terre des Hommes International on 27 June 2011 in Brussels.

Interview 6 conducted with a JHA Councillor of the Permanent Representation of the United Kingdom to the EU on 30 June 2011 in Brussels.

Interview 7 conducted with a former representative of Terre des Hommes International on 4 July 2011 in Brussels.

Interview 8 conducted with a representative of the Jesuit Refugee Service Europe on 5 July 2011 in Brussels.

Interview 9 conducted with a representative of the Red Cross Europe on 5 July 2011 in Brussels. Interview 10 conducted with a representative of the European Women's Lobby on 6 July 2011 in Brussels.

Interview 11 conducted with a representative of the Churches' Commission for Migrants in Europe on 7 July 2011 in Brussels.

Interview 12 conducted by phone with a JHA Councillor of the Permanent Representation of Germany to the EU on 8 July 2011. 
Interview 13 conducted with a JHA Councillor of the Permanent Representation of Latvia to the EU on 11 July 2011 in Brussels.

Interview 14 conducted with a JHA Councillor of the Permanent Representation of Hungary to the EU on 12 July 2011 in Brussels.

Interview 15 conducted with a JHA Councillor of the Permanent Representation of Belgium to the EU on 13 July 2011 in Brussels.

Interview 16 conducted with a Member of the European Parliament on 13 July 2011 in Brussels.

Interview 17 conducted with a representative of the European Council on Refugees and Exiles on 14 July 2011 in Brussels.

Interview 18 conducted with a Commission desk officer on 15 July 2011 in Brussels.

Interview 19 conducted with an Assistant to a Member of the European Parliament on 15 July 2011 in Brussels.

Interview 20 conducted with a representative of the Amnesty International European Union Office on 16 July 2011 in Brussels.

Interview 21 conducted with a JHA Councillor of the Permanent Representation of Greece to the EU on 19 July 2011 in Brussels.

Interview 22 conducted with an Assistant to a Member of the European Parliament on 20 July 2011 in Brussels.

Interview 23 conducted with a representative of the European Region of the International Lesbian, Gay, Bisexual, Trans and Intersex Association on 20 July 2011 in Brussels.

Interview 24 conducted with a JHA Councillor of the Permanent Representation of the Netherlands to the EU on 26 July 2011 in Brussels.

Interview 25 conducted with a JHA Councillor of the Permanent Representation of Austria to the EU on 27 July 2011 in Brussels.

Interview 26 conducted with a JHA Councillor of the Permanent Representation of Poland to the EU on 29 July 2011 in Brussels.

Interview 27 conducted with an Assistant to a Member of the European Parliament on 20 July 2011 in Brussels.

Interview 28 conducted by phone with a former representative of the European Council on Refugees and Exiles on 15 August 2011.

Interview 29 conducted by phone with a representative of Asylum Aid on 1 September 2011.

Interview 30 conducted by email with an Assistant to a Member of the European Parliament on 9 December 2011.

\section{About the authors}

Christian Kaunert, School of Humanities, University of Dundee, United Kingdom. Corresponding author.

E-mail: c.kaunert@dundee.ac.uk.

Sarah Léonard, School of Humanities, University of Dundee, United Kingdom. E-mail: s.l.leonard@dundee.ac.uk 
UlrikeHoffmann, School of Humanities, Languages and Social Sciences, University of Salford, United Kingdom.

E-mail: ulr.hoffmann@googlemail.com.

2013 Kaunert, Léonard \& Hoffmann / Amsterdam University Press.

This is an Open Access article distributed under the terms of the Creative Commons Attribution License (http:// creativecommons.org/licenses/by/2.o), which permits unrestricted use, distribution, and reproduction in any medium, provided the original work is properly cited. 